\title{
Wheat yield and seed physiological quality affected by initial seed vigor, sowing density, and environmental conditions
}

\author{
Rendimento de grãos e qualidade fisiológica de \\ sementes de trigo influenciados pelo vigor inicial \\ da semente, densidade de semeadura e condições \\ ambientais
}

\begin{abstract}
Jéssica de Lucena Marinho ${ }^{1 *}$; Sérgio Ricardo Silva ${ }^{2} ;$ Diogo Nascimento de Souza ${ }^{3}$; Inês Cristina de Batista Fonseca4; José Henrique Bizzarri Bazzo4;

Claudemir Zucareli ${ }^{4}$
\end{abstract}

\section{Highlights}

Increase sowing density up to 450 seeds $\mathrm{m}^{-2}$ favored productive performance of wheat. Seeding densities between 250 and 350 seeds $\mathrm{m}^{-2}$ favored seed production in Londrina. Gralha-Azul in Londrina, and Sabiá in Ponta Grossa showed best productive performance. Vigorous seeds favored the establishment of wheat in unfavorable conditions.

\begin{abstract}
Optimization of seed density range, combined with the use of quality seeds may help generate more profit from wheat production, as these factors affect grain yield and the quality of seeds. The aim of this study was to evaluate the effects of initial vigor level and sowing densities on the productive performance of the plants and the physiological performance of the seeds of two wheat cultivars in two cultivation environments. The experiment was carried out in the cities of Londrina and Ponta Grossa, Paraná, Brazil, in a randomized block design with four replications, following a $2 \times 2 \times 4$ factorial scheme with two levels of seed vigor (high and low), two cultivars (BRS Gralha-Azul and BRS Sabiá), and four sowing densities (150, 250, 350, and 450 seeds $\mathrm{m}^{-2}$ ). The following characteristics were evaluated: emerged seedlings, shoot dry matter, spike density, vegetation index, and grain yield. Additionally, the physiological potential of the seeds produced in

1 Doctoral Student in the Graduate Program in Agronomy, Center for Agricultural Sciences, State University of Londrina, UEL, Londrina, PR, Brazil. E-mail: jlmarinho@live.com

2 Researcher, Empresa Brasileira de Pesquisa Agropecuária, EMBRAPA Trigo, Passo Fundo, RS, Brazil. E-mail: sergio. ricardo@embrapa.br

3 M.e, Agronomist employed in Syngenta Seeds, Maringá, PR, Brazil. E-mail: di.nsouza@gmail.com

${ }^{4}$ Profs. Drs., Department of Agronomy, Center for Agricultural Sciences, UEL, Londrina, PR, Brazil. E-mail: inescbf@uel. br; josebazzo@uel.br; claudemircca@uel.br

* Author for correspondence
\end{abstract}

Received: Nov. 17, 2020 - Approved: Mar. 19, 2021 
Londrina was evaluated by first germination count, germination, accelerated aging, seedling emergence, and emergence speed index tests. The increase in density up to 450 seeds $\mathrm{m}^{-2}$ favored the productive performance of the crop in both cultivation environments; however, it reduced the physiological performance of the seeds produced in Londrina. The cultivars BRS Gralha-Azul and BRS Sabiá had better performance and grain yield in Londrina and Ponta Grossa, respectively. High-vigor seeds favored the establishment of the stand, especially under unfavorable environmental conditions.

Key words: Germination. Plant population. Seed quality. Triticum aestivum L.

\section{Resumo}

O ajuste da densidade de semeadura ótima para a cultura trigo aliado à utilização de sementes de qualidade pode contribuir para gerar maior lucratividade na produção de trigo, pois esses fatores afetam o rendimento de grãos e a qualidade das sementes. O objetivo do trabalho foi avaliar os efeitos do nível de vigor inicial e das densidades de semeadura sobre o desempenho produtivo das plantas e o desempenho fisiológico das sementes de duas cultivares de trigo em dois ambientes de cultivo. $\mathrm{O}$ experimento foi conduzido nas cidades de Londrina e em Ponta Grossa, Paraná, Brasil, em delineamento experimental de blocos casualizados com quatro repetições, em esquema fatorial $2 \times 2 \times 4$, sendo avaliados dois níveis de vigor de sementes (alto e baixo), duas cultivares (BRS Gralha-Azul e BRS Sabiá) e quatro densidades de semeadura $\left(150,250,350\right.$ e 450 sementes $\left.\mathrm{m}^{-2}\right)$. As seguintes características foram avaliadas: número de plântulas emergidas, matéria seca da parte aérea de plantas, densidade de espigas, índice de vegetação e rendimento de grãos. Adicionalmente, foi avaliado o potencial fisiológico das sementes produzidas em Londrina pelos testes de primeira contagem, germinação, envelhecimento acelerado, emergência de plântulas e índice de velocidade de emergência. O aumento da densidade até 450 sementes $\mathrm{m}^{-2}$ favoreceu o desempenho produtivo da cultura nos dois locais de cultivo, porém, reduziu o desempenho fisiológico das sementes produzidas em Londrina. As cultivares BRS Gralha-Azul e BRS Sabiá apresentaram desempenho e rendimento de grãos superiores em Londrina e Ponta Grossa, respectivamente. Sementes de alto vigor favorecem o estabelecimento do estande, principalmente em condições ambientais desfavoráveis.

Palavras-chave: Germinação. População de plantas. Qualidade de sementes. Triticum aestivum L.

\section{Introduction}

Wheat (Triticum aestivum L.) is one of the most commonly consumed cereals worldwide, mainly because of its multiple purposes, making it an important source of calories for human consumption (Long \& Ort, 2010). Despite the increase in national production of this cereal in 2020, production in Brazil is still unable to meet the country's demand, generating dependence on imports (Ministério da Agricultura, Pecuária e Abastecimento [MAPA], 2020). Thus, achieving maximum productive potential for the crop by adopting appropriate management techniques, and using promising genotypes and quality seeds is essential for meeting the internal demand in Brazil.

The choice of cultivars adapted to the different cultivation regions is the main factor to be considered when planting the crop as it directly influences the growth, development, and productive potential of wheat (R. R. Silva et 
al., 2011). In order to identify the best genotype, it is necessary to consider the cultivation environment and the genotype $\times$ environment interaction, because although wheat has a certain plasticity in the components of grain yield in response to environmental changes, edaphoclimatic conditions extensively affect the expression of genes associated with genotypes (Tavares, Foloni, Bassoi, \& Prete, 2014).

The physiological potential of seeds, evaluated by germination and vigor tests, influences the initial establishment of the crop, plant growth rate, grain yield, and the quality of the seeds produced (Mondo, Cicero, Dourado, Pupim, \& Dias, 2012; Oliveira et al., 2014). Vigorous seeds have a greater capacity to resist adverse field conditions, and display higher speed of germination, emergence, and initial development, resulting in rapid and uniform growth of seedlings (Sbrussi \& Zucareli, 2014). In contrast, seeds with less vigor generate more abnormal seedlings, causing failures, which compromises the establishment of the stand and the overall crop performance (Henning et al., 2010).

In addition to the use of high-quality seeds, adjusting the sowing density for each genotype is essential for achieving maximum productive potential, because the number of plants per unit area directly influences intra and interspecific competition, influencing the use of solar radiation and other environmental resources by the plants (Tavares et al., 2014). Genotypes with greater tillering potential can maintain expressive grain and seed productivity even when grown at low densities. On the other hand, cultivars with low tillering depend on a higher sowing density to obtain high yield, as they are less efficient in compensating for the smaller number of ears per unit area (Valério et al., 2009). In addition, the use of vigorous seeds, especially at lower sowing densities, provides greater productive potential, because the vigor favors proper establishment of the stand, avoiding failures, which results in higher production per unit area, less incidence of weeds, and better use of environmental resources (Abati, Brzezinski, Zucareli, Foloni, \& Henning, 2018). Abati et al. (2017) studied the influence of seed vigor and sowing density on the emergence of wheat seedlings, and found that vigorous seeds resulted in higher seedling emergence, regardless of the sowing density.

Based on the above findings, the aim of this study was to evaluate influence of initial vigor level and sowing densities on the productive performance of the plants and the physiological performance of the seeds of two wheat cultivars in two cultivation environments.

\section{Material and Methods}

\section{Study location and experimental design}

The experiments were conducted under two cultivation environments in the state of Paraná, Brazil, with contrasting edaphoclimatic characteristics, i.e., in Londrina and Ponta Grossa. In Londrina, the experiment was carried out on an experimental farm of Embrapa Soja (2311'37" S, 51011'03" W; altitude, $628 \mathrm{~m}$ ). The relief is low undulating, and the soil of the experimental area is a dystrophic Red Latosol with a clayey texture (Empresa Brasileira de Pesquisa Agropecuária [EMBRAPA], 2013); the regional climate, according to the Köeppen classification, is humid subtropical (Cfa), with hot and rainy summers, $21.2{ }^{\circ} \mathrm{C}$ mean temperature, average annual rainfall of 1,392 
$\mathrm{mm}$, infrequent frosts, and no defined dry season. In Ponta Grossa, the experiment was carried out at the Embrapa Soja experimental farm (2509'31" S, 5004'22" W; altitude, 886 $\mathrm{m})$. The relief is low undulating, and the soil of the experimental area is a medium-textured dystrophic Red Latosol (EMBRAPA, 2013); the regional climate is humid subtropical mesothermal ( $\mathrm{Cfb})$, with an average annual temperature of $17.5{ }^{\circ} \mathrm{C}$, mild summers, average annual precipitation of $1,495 \mathrm{~mm}$, well-distributed rains, and frequent frosts. The data for rainfall and maximum, average, and minimum daily temperature during the cultivation period for both experimental areas are shown in Figure 1.

Prior to the commencement of the experiments, soil samples were collected from the experimental areas from the 0-20 $\mathrm{cm}$ layer for chemical analysis. The results for Londrina and Ponta Grossa were as follows: $\mathrm{pH}\left(\mathrm{H}_{2} \mathrm{O}\right), 5.3$ and 5; $\mathrm{P}$ (Mehlich-1), 31.7 and $10.4 \mathrm{mg} \mathrm{dm}^{-3} ; \mathrm{H}+\mathrm{Al}, 3.46$ and $4.35 \mathrm{cmol}_{\mathrm{c}} \mathrm{dm}^{-3}$; $\mathrm{K}, 0.95$ and $0.34 \mathrm{cmol}_{\mathrm{c}} \mathrm{dm}^{-3} ; \mathrm{Ca}, 4.8$ and 3.12 $\mathrm{cmol}_{\mathrm{c}} \mathrm{dm}^{-3} ; \mathrm{Mg}, 1.87$ and $1.19 \mathrm{cmol}_{\mathrm{c}} \mathrm{dm}^{-3}$; Cation Exchange Capacity (CEC), 10.36 and 9 $\mathrm{cmol}_{\mathrm{c}} \mathrm{dm}^{-3}$; base saturation (V), $66 \%$ and $52 \%$, respectively.

The experiment was performed following a randomized block design with four replications, in a $2 \times 2 \times 4$ factorial scheme with two wheat cultivars (BRS Gralha-Azul and BRS Sabiá), two levels of initial seed vigor (vigorous seeds and less vigorous seeds), and four sowing densities $(150,250,350$, and 450 viable seeds $\mathrm{m}^{-2}$ ). BRS Sabiá presents an early cycle, commercial class: wheat bread, with wide adaptation, fast initial establishment, and less tillering capacity compared to BRS Gralha-Azul, with a prescribed sowing density of 300 to 350 seeds $\mathrm{m}^{-2}$ (Bassoi \& Foloni, 2015a; Bassoi et al., 2019). BRS Gralha-Azul has a medium cycle, commercial class: wheat bread/breeder, with wide adaptation, better tillering capacity, and a lower sowing density compared to BRS Sabiá, at around 250 to 300 seeds $\mathrm{m}^{-2}$ (Bassoi \& Foloni, 2015b; Bassoi et al., 2019). 

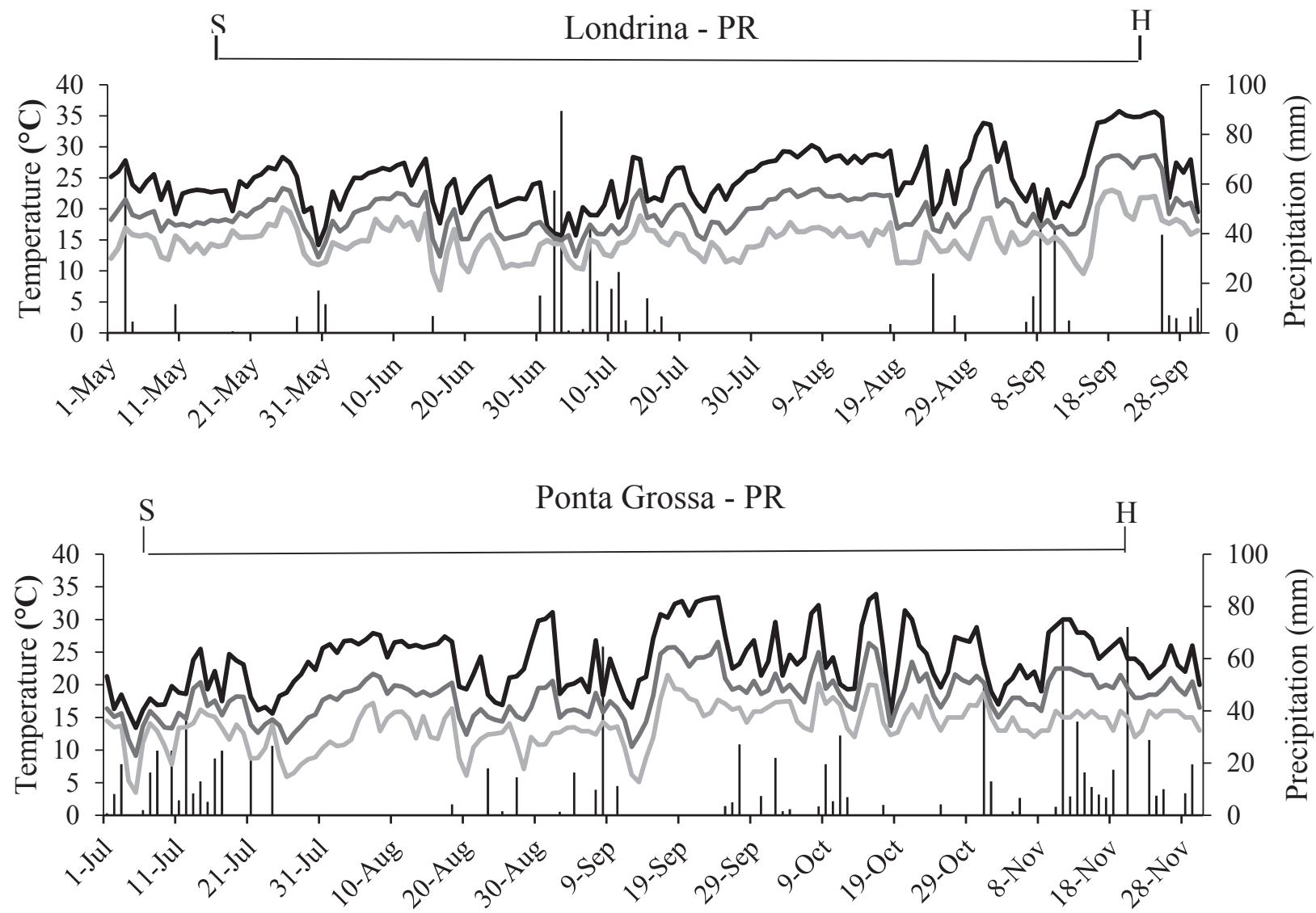

Figure 1. Average daily data of maximum (upper curve), average (central curve) and minimum (lower curve) temperatures and precipitation (vertical bars) during the experiments in Londrina and Ponta Grossa. S, sowing; $\mathrm{H}$, harvest.

\section{Execution of experiments}

The seeds considered to be less vigorous were obtained from the vigorous seed lots through accelerated artificial aging, which involved packaging the seeds in plastic gerbox boxes with screened supports, containing
$40 \mathrm{~mL}$ of distilled water at the bottom, and subsequent incubation in a BOD chamber at $42{ }^{\circ} \mathrm{C}$ for $48 \mathrm{~h}$. The seeds not artificially aged (vigorous) and those subjected to accelerated aging (inferior vigor) were characterized (Table 1) based on the initial physiological quality, using the tests described subsequently. 
Table 1

Average values of the physiological attributes of vigorous and non-vigorous seeds of BRS Gralha-Azul and BRS Sabiá cultivars used in the experiment

\begin{tabular}{ccccc}
\hline \multirow{2}{*}{ Vigor } & \multicolumn{5}{c|}{ Characteristic } \\
\cline { 2 - 5 } & FC (\%) & G (\%) & SE (\%) & ESI \\
Vigorous & 91 & \multicolumn{2}{c|}{ BRS Gralha-Azul } \\
Non-vigorous & 74 & 96 & 86 & 12.81 \\
& & 88 & 78 & 11.61 \\
Vigorous & 91 & 97 & BRS Sabiá & 12.97 \\
Non-vigorous & 87 & 95 & 85 & 11.75 \\
\hline
\end{tabular}

FC: first germination count; G: germination; SE: seedling emergence; ESI: emergency speed index.

Germination was carried out with eight subsamples of 50 seeds, distributed on Germitest ${ }^{\circledR}$ paper moistened with distilled water in a proportion of 2.5 times the dry mass of the dry substrate. The paper rolls with the seeds were kept in a germinator at a temperature of $20^{\circ} \mathrm{C}$. The evaluation consisted of two counts, the first at four days (first count), and the second at eight days (final count) after starting the test, followed by computation of the percentage of normal seedlings (MAPA, 2009).

Emergence of seedlings in sand was evaluated in a greenhouse with four replications of 50 seeds per treatment, sown at a depth of $3 \mathrm{~cm}$, in plastic trays containing sand, washed prior to the experiment. Humidity was maintained with periodic irrigation. The number of normal seedlings that emerged was evaluated on the fifteenth day.

Emergence speed index (ESI) was assessed with the seedling emergence test in sand through daily counts of the number of normal seedlings emerged, without discarding them, thus, yielding a cumulative value. From these results, the ESI was calculated using the formula proposed by Maguire (1962).

Vigorous and less vigorous seeds were used in the field experiments. The plants were grown under a no-tillage system in an area previously occupied by soybean. Based on the chemical characteristics of the soil in the experimental areas, base fertilization was performed in the sowing furrow, using 250 $\mathrm{kg} \mathrm{ha}^{-1}$ of the formulated fertilizer 08-15-15 (20 kg ha-1 $\mathrm{N}+37.5 \mathrm{~kg} \mathrm{ha}^{-1} \mathrm{P}_{2} \mathrm{O}_{5}+37.5 \mathrm{~kg} \mathrm{ha}^{-1}$ $\mathrm{K}_{2} \mathrm{O}$ ). Nitrogen fertilization by side dressing was carried out at the beginning of the tillering stage, using $40 \mathrm{~kg} \mathrm{ha}^{-1} \mathrm{~N}$ (in the form of ammonium nitrate).

Sowing was carried out mechanically on May 18 in Londrina, and on July 7 in Ponta Grossa, according to the period indicated by the agricultural climate risk zoning for each municipality (MAPA, 2015). The seeds were treated with insecticide (imidacloprid) and fungicide (carboxin + thiram) before sowing. Phytosanitary treatments for disease control and other cultural treatments were carried out according to the needs and indications 
of the Brazilian Wheat and Triticale Research Commission for wheat culture (S. R. Silva, Bassoi \& Foloni, 2018).

The experimental plots consisted of ten rows, spaced $0.20 \mathrm{~m}$ apart, and were $6 \mathrm{~m}$ long, totaling an area of $12 \mathrm{~m}^{2}$ per plot. For the evaluations, the six central rows were considered as useful areas, leaving $0.5 \mathrm{~m}$ at the final and initial ends of the plot as a border. The harvest was carried out mechanically, on September 18 in Londrina, and on November 20 in Ponta Grossa after the grains reached harvest maturity, characterized by hardening of the caryopsis, plants displaying a dry aspect, and grains having a moisture content of approximately $13 \%$.

Evaluation of agronomic characteristics and productive potential

Agronomic characteristics of the wheat plants were evaluated for both cultivation environments following the analyses described subsequently.

Number of seedlings emerged per $\mathrm{m}^{2}$ was counted at fifteen days after sowing, in a total area of $0.75 \mathrm{~m}^{2}$ per plot, which comprised three $0.25 \mathrm{~m}^{2}$ subsamples.

Normalized Difference Vegetation Index (NDVI) was assessed using a GreenSeeker ${ }^{\circledR}$ equipment during the stalk stretching stage (Zadoks GS 30). The evaluation was performed by positioning the device approximately $30 \mathrm{~cm}$ above the canopy, covering the useful area of the experimental plot at a constant speed.

Shoot dry matter (SDM) was obtained when wheat plants were at the physiological maturity stage of the grains (Zadoks GS 92). Sampling was carried out in two $0.5 \mathrm{~m}$-long crop lines, totaling $0.2 \mathrm{~m}^{2}$ per experimental plot. The plants were cut close to the soil surface, and the plant material was dried in a stove with forced air circulation at $60^{\circ} \mathrm{C}$, until it reached a constant mass. The dried plants were weighed, followed by the screening and weighing of the grains. SDM was obtained by subtracting the grain weight from the total weight of the plants.

Number of ears $\mathrm{m}^{-2}$ was quantified by counting the total number of ears within the collected area $\left(0.25 \mathrm{~m}^{2}\right)$ at harvest maturity.

Grain yield was estimated by mechanical harvesting of plant grains contained in the useful area of the plot. After screening, the grains were weighed, and the results were expressed in $\mathrm{kg} \mathrm{ha}^{-1}$ (with $13 \%$ moisture content).

Evaluation of the physiological potential of seeds

In Londrina, physiological quality of the seeds of both cultivars was evaluated by first germination count, germination, seedling emergence, and ESI as described previously. In addition, the accelerated aging test was carried out in gerbox boxes containing $40 \mathrm{~mL}$ of distilled water, fixed with a wire mesh tray for distributing the seeds in a single layer. The boxes were covered, and kept at $43^{\circ} \mathrm{C}$ for $48 \mathrm{~h}$ (Ohlson, Krzyzanowski, Caieiro, \& Panobianco, 2010). Subsequently, the germination test was performed at a temperature of $20^{\circ} \mathrm{C}$ (MAPA, 2009), with counting at four days after sowing. The results were expressed as the percentage of normal seedlings.

Physiological potential of the seeds produced in Ponta Grossa was not evaluated, because there was no seed production in this 
environment due to lower germination rate than the standard established for this crop (MAPA, 2013).

\section{Statistical analysis}

Data were subjected to normality and homogeneity analysis of the deviations, and subsequently to analysis of variance. Average values obtained for sowing density were subjected to regression analysis at 5\% significance, and the parameters were adjusted by linear, quadratic, or quadratic square root models.

\section{Results and Discussion}

\section{Seedling emergence, NDVI, and SDM}

There was a simple effect (nonsignificant interactions) of the cultivar factor for SDM in Londrina, and for seedling emergence in both cultivation environments. For the number of emerged seedlings, BRS Sabiá presented better results than BRS Gralha-Azul. For SDM in Londrina, the cultivar BRS GralhaAzul showed better performance (Table 2).

The genotypes exhibited different behaviors in the same region of cultivation. This can be attributed to the difference in the ability of genetic materials to adapt to environments, the difference in cycle length (which influences the definition of grain yield components), and the physiological maturation period (Guarienti, Ciacco, Cunha, Ducca, \& Camargo, 2005).

There was also a significant effect of the initial seed vigor level on the number of seedlings that emerged in Ponta Grossa, with high-vigor seeds performing better (Table 2).

The sowing density factor also had an effect on number of emerged seedlings in both regions (Table 2), fitted to increasing linear equations (Figures 2B and 2C), depicting an increase in seedling density in response to the increase in sowing density. However, this increase in emerged seedlings was not proportional to the increase in sowing density, indicating that other factors, such as vigor, sowing quality, and soil characteristics, influenced the establishment of seedlings. These results corroborate those of Abati et al. (2018), whoobserved that theincreaseinsowing density promoted greater seedling emergence, with the highest seedling emergence in the highest density studied ( 400 seeds $\mathrm{m}^{-2}$ ) for two vigor levels, viz., vigorous and non-vigorous seeds. It may be noted that, in most cases, the population of plants established is generally below the programmed density, which is expected, because germination, vigor, and edaphoclimatic conditions directly affect the establishment of the production field; however, densities are planned to maintain high grain yield levels. 


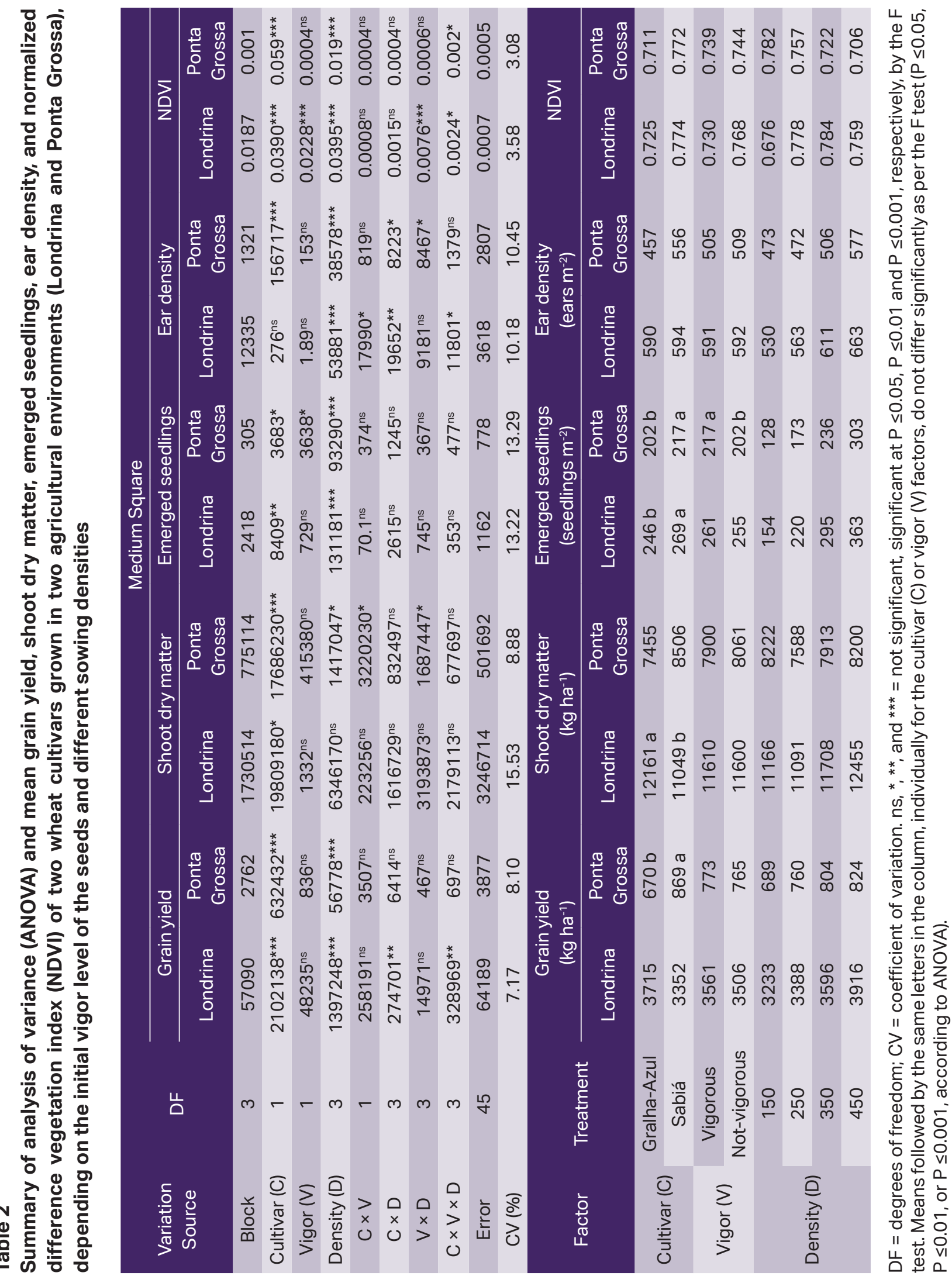


Seed vigor directly affected the establishment and development of wheat in Ponta Grossa, where vigorous seeds resulted in a higher percentage of emerged seedlings as compared with non-vigorous seeds (Table 2). Similar results were obtained by Abati et al. (2018), who observed that the use of vigorous seeds resulted in a greater number of emerged seedlings when compared to non-vigorous seeds. This is due to the fact that seeds with high physiological potential have a higher germination speed, emergence, and initial seedling development in the field, even under unfavorable conditions, resulting in better stand establishment (Carvalho \& Nakagawa, 2012). It may be noted that in Ponta Grossa, there was water stress caused by excessive rain during the period of germination and seedling emergence (Figure 1). In this case, the use of vigorous seeds contributed to the establishment of a greater number of seedlings per unit area, since these seeds have a greater capacity to resist adverse conditions in the field (Sbrussi \& Zucareli, 2014).

For SDM in Ponta Grossa, there was an interaction between cultivar and vigor (Table 2). The average SDM production of BRS Sabiá was $14.1 \%$ higher than BRS Gralha-Azul at the two levels of vigor. Further, it was observed that for BRS Gralha-Azul, plants derived from nonvigorous seeds showed higher SDM $(7760 \mathrm{~kg}$ $\left.\mathrm{ha}^{-1}\right)$ than plants derived from vigorous seeds $\left(7150 \mathrm{~kg} \mathrm{ha}^{-1}\right)$. For BRS Sabiá, SDM for the two levels of vigor did not differ significantly (data not shown). The difference in cultivar behavior can be attributed to the genotypic variations between them in terms of their ability to cope with different cultivation conditions (by tillering) (Abati et al., 2018). BRS Sabiá had a higher compensation capacity than BRS Gralha-Azul in the Ponta Grossa environment, with higher SDM, even with the use of non-vigorous seeds.
SDM evaluated in Ponta Grossa also showed a significant interaction between vigor and density (Table 2). Plants from low-vigor seeds showed a reduction of approximately $8 \%$ in SDM as the sowing density increased (Figure 2F). For plants derived from high-vigor seeds, no regression adjustment was observed in response to increased density. There was no significant difference between vigor levels at all evaluated sowing densities, considering each seeding density individually.

A significant effect of the interaction between cultivar $\times$ vigor $\times$ sowing density was observed for the NDVI in Londrina and Ponta Grossa (Table 2). In Londrina, there was a significant initial increase in NDVI with the increase in sowing density, with an average maximum point at approximately 300 seeds $\mathrm{m}^{-2}$ for both cultivars and levels of vigor (Figure $2 \mathrm{G})$. This increase was expected, because the vegetation cover increases along with the greenness due to the higher sowing density, and consequently, the NDVI is also increased (Ramme, Lamparelli, \& Rocha, 2010). It was also observed that the increase was smaller for plants derived from non-vigorous seeds, whereas, for those derived from vigorous seeds, there was a lower rate of decrease, regardless of the cultivar. At densities of 150 and 450 seeds $\mathrm{m}^{-2}$, it was observed that the NDVI of BRS Gralha-Azul derived from vigorous seeds was lower than that of plants derived from nonvigorous seeds of BRS Sabiá. This behavior may be attributed to greater intraspecific competition, since vigorous seeds and higher sowing densities result in more complete stands, which reduces tillering and can lead to the suppression of less vigorous plants, resulting in less vegetation cover (Mondo et al., 2012). At the other densities, no significant difference was observed between the cultivars and the vigor levels. 

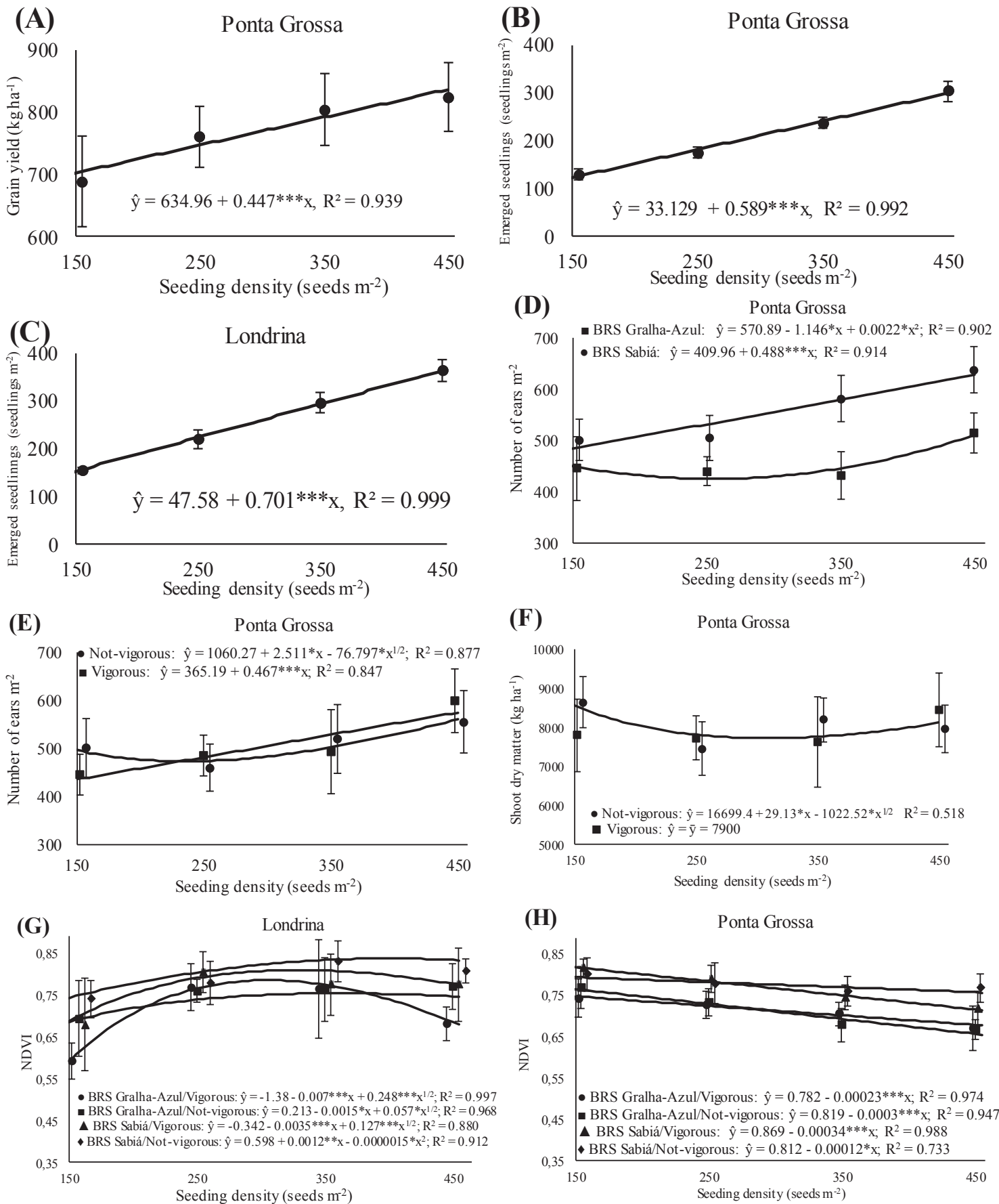

Figure 1. Grain yield (A), emerged seedlings ( $B$ and $C$ ), number of ears ( $D$ and $E$ ), shoot dry matter $(F)$, and normalized difference vegetation index - NDVI (G and $H)$ of wheat as a function of sowing density in two cultivation environments (Londrina and Ponta Grossa). *** ,** and *: significance of the coefficients of the regression models, by the F-test at $P<0.001, P<0.01$ and $P<0.05$, respectively. Vertical error bars indicate the $95 \%$ confidence interval for the mean ( $n=16$ for isolated density effect, $n=8$ for double interactions, and $n=4$ for triple interactions) for each density. In order to avoid overlapping the vertical confidence interval bars, the observed points (circles, squares, triangles and diamonds) were displaced on the abscissa. 
In Ponta Grossa, NDVI showed a decreasing linear response for both cultivars and vigor levels in response to the increase in sowing density (Figure $2 \mathrm{H}$ ), which may be due to higher intraspecific competition, since the same amount of resources (fertilizer and water) were available at low and high densities. More individuals per area at higher densities resulted in greater competition, reduced tillering, and suppressed the underdeveloped plants, reducing plant cover. Despite the reduction observed with the increase in density, the NDVI values observed in Ponta Grossa were high, even at the highest densities, indicating adequate vegetation cover. Additionally, it was observed that BRS Sabiá had a higher NDVI than BRS Gralha-Azul at a density of 150 seeds $\mathrm{m}^{-2}$, considering the plants from vigorous seeds (Figure $2 \mathrm{H}$ ). There was also a significant difference between BRS Sabiá derived from non-vigorous seeds and BRS Gralha-Azul from seeds of both vigor levels, at densities of 350 and 450 seeds $\mathrm{m}^{-2}$, with better performance of BRS Sabiá compared to BRS Gralha-Azul.

\section{Ear density and grain yield}

There was a significant effect of cultivar on grain yield in Ponta Grossa, with BRS Sabiá yielding better results than BRS Gralha-Azul (Table 2). An isolated effect of the sowing density factor was also observed for grain yield in Ponta Grossa, showing a positive linear relation, with an increase of $45 \mathrm{~kg} \mathrm{ha}^{-1}$ for every 100 seeds $\mathrm{m}^{-2}$ (Figure 2A). These results corroborate those of Valério et al. (2013), who also observed an increase in grain yield in wheat as the sowing density increased to around 450 seeds $\mathrm{m}^{-2}$. This increase in grain yield can be attributed to the increase in grain yield components observed in response to the increase in density (Figures 2D and 2E).
Ear density in Ponta Grossa was influenced by the interaction between cultivar and sowing density (Table 2). BRS Sabiá showed a positive linear relation with sowing density, with a $27 \%$ increase in the number of ears $\mathrm{m}^{-2}$ in response to an increase in sowing density to 300 seeds $\mathrm{m}^{-2}$ (Figure 2D). In contrast, ear density in BRS Gralha-Azul was adjusted to a quadratic equation, with a minimum point at 255 seeds $\mathrm{m}^{-2}$. It was also observed that BRS Sabiá had a higher number of ears per unit area compared to BRS Gralha-Azul at higher sowing densities ( 350 and 450 seeds $\mathrm{m}^{-2}$ ).

Due to the different tillering capabilities, wheat genotypes are affected differently by sowing density (Tavares et al., 2014). For cultivars with lower tillering capacity (such as BRS Sabiá), a higher sowing density is prescribed, as these cultivars achieve higher grain yields at higher sowing densities due to the production of more ears per unit area. For cultivars with higher tillering (such as BRS Gralha-Azul), the prescribed sowing density is lower, as these cultivars are able to occupy the available space and maintain production through the formation of fertile tillers (Valério et al., 2009). This explains the better performance of BRS Sabiá at higher sowing densities. In addition, higher plant populations promote greater intraspecific competition (Abati et al., 2017), mainly for genotypes with more tillering, such as BRS Gralha-Azul, which explains the lower number of ears per unit area for this cultivar compared to BRS Sabiá, since competition between plants and tillers can increase the incidence of infertile tillers and reduce the number of ears per unit area. Valério et al. (2008) studied the development of tillers in wheat genotypes cultivated at different sowing densities, and observed that cultivars with lower tillering potential gave higher grain yields at higher sowing density. Further, they 
also observed that at high sowing densities, cultivars with more tillering showed greater tiller senescence.

The ear density evaluated in Ponta Grossa also showed a significant interaction between vigor and sowing density (Table 2). There was a linear increase in the density of ears in plants from vigorous seeds, whereas for plants from non-vigorous seeds, there was less variation, with a quadratic regression adjustment in this variable (Figure 2E). The values observed for ear density in treatments with high and low vigor were statistically equal, considering each seeding density individually.

The interaction between cultivar $\times$ vigor $\times$ sowing density was significant for grain yield and ear density in Londrina (Table 2). There was an increase in grain yield in Londrina in response to the increase in sowing density for both cultivars at the two initial seed vigor levels (Figure 3A). For BRS Gralha-Azul, an increasing linear response was observed, with an increase of $22.7 \%$ and $10.9 \%$ for plants from vigorous and non-vigorous seeds, respectively. The cultivar BRS Sabiá also showed a linear increase in grain yield in plants from vigorous seeds, with an increase of up to $17.9 \%$. In contrast, plants from non-vigorous seeds of the same cultivar showed a quadratic relation, with the minimum point around 216 seeds $\mathrm{m}^{-2}$. In other words, the grain yield decreased and reached the minimum level at a density of 216 seeds $\mathrm{m}^{-2}$. The cultivars differed in terms of grain yield for plants from non-vigorous seeds, and at densities of 250 and 350 seeds $\mathrm{m}^{-2}$, with better performance of BRS Gralha-Azul compared with BRS Sabiá.

Ear density increased linearly with the increase in sowing density for BRS GralhaAzul in Londrina at both vigor levels. However, there was a higher rate of increase for plants from non-vigorous seeds (Figure 3B). For BRS Sabiá, plants from vigorous seeds showed a small decrease in the number of ears per unit area with an increase in sowing density, but with a subsequent increase of $17.7 \%$ in the density from 350 to 450 seeds $\mathrm{m}^{-2}$. Plants from non-vigorous seeds of BRS Sabiá did not respond to the increase in sowing density. At a density of 150 seeds $\mathrm{m}^{-2}$, it was observed that the treatment with BRS Gralha-Azul from non-vigorous seeds presented a lower ear density than the other treatments. The other treatments did not differ from each other. For the other densities evaluated, no significant differences were observed between the cultivars and vigor levels. 

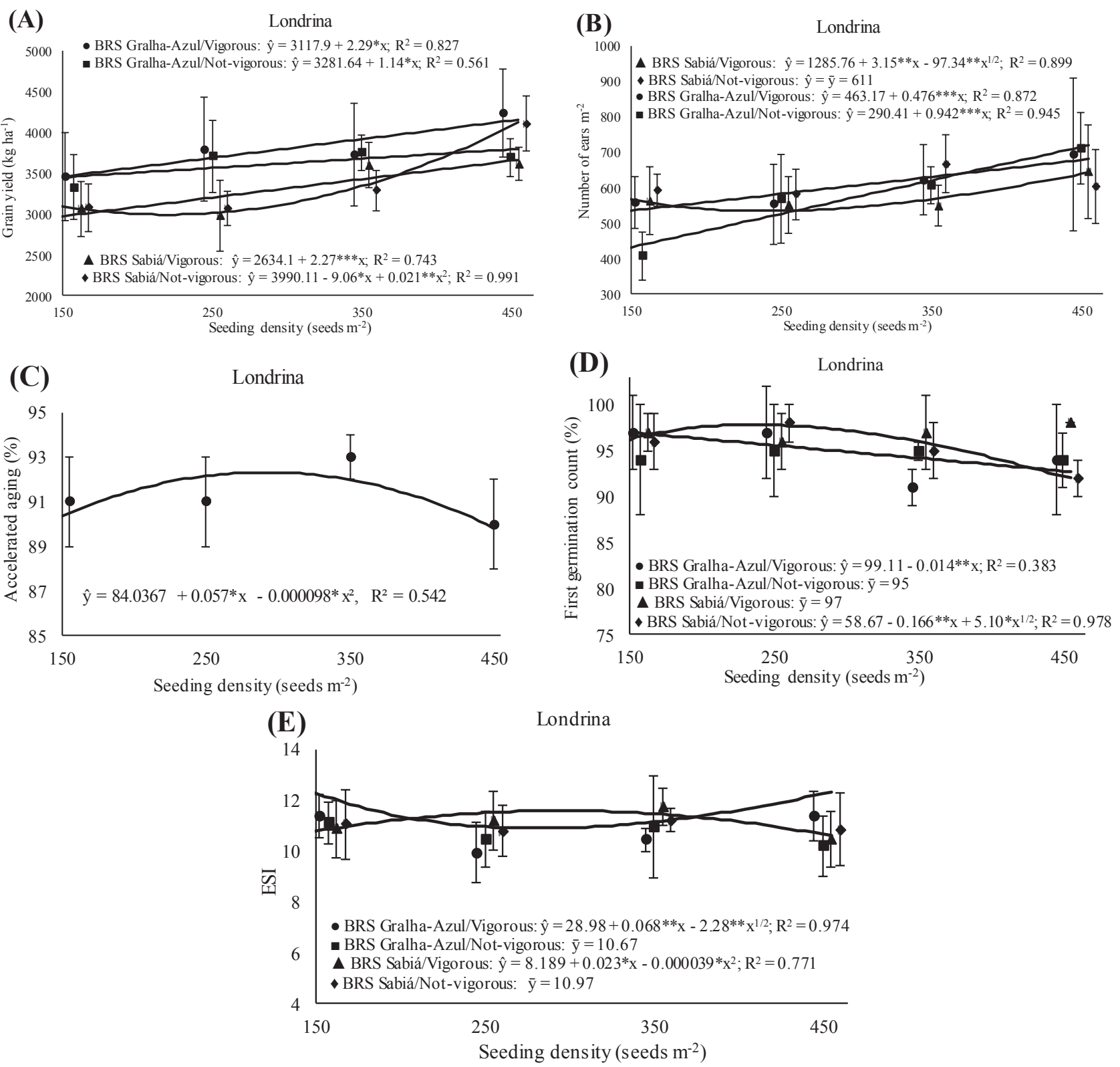

Figure 3. Grain yield (A), number of ears (B), accelerated aging (C), first germination count (D), and emergence speed index (ESI) (E) of wheat as a function of sowing density in Londrina. ${ }^{* * *},{ }^{* *}$ and *: significance of the coefficients of the regression models as per the F-test at $P<0.001, P$ $<0.01$, and $P<0.05$, respectively. Vertical error bars indicate the $95 \%$ confidence interval, for the mean ( $n=16$ for density effect, and $n=4$ for triple interactions) for each density. In order to avoid overlapping the vertical confidence interval bars, the observed points (circles, squares, triangles and diamonds) were displaced on the abscissa. 
The small influence of initial seed vigor level in the Londrina environment may be associated with the favorable weather conditions prevalent in that region during the experiments (Figure 1). The effect of vigor on stand establishment and initial seedling development were more pronounced under unfavorable conditions. Rossi, Cavariani and França (2017) studied the physiological potential of seeds in soybean productive performance, and found that the absence of significant differences between the levels of vigor in grain yield was due to the adequate edaphoclimatic conditions. This corroborates the results obtained for Londrina in the present study.

Increase in sowing density favored the productive performance of wheat. The observed increase was due to the larger number of ears per unit area owing to a larger number of plants established under higher sowing density. Although an increase in plant density leads to a reduction in the number of tillers per plant, there is still a higher incidence of main stems and fertile tillers per unit area, increasing grain yield, because of the larger number of ears and grains formed (Valério et al., 2013).
In Londrina, BRS Sabiá performed better than BRS Gralha-Azul only in terms of the number of emerged seedlings. Conversely, BRS Gralha-Azul showed better performance in context of SDM and grain yield at densities of 250 and 350 seeds $\mathrm{m}^{-2}$, indicating a greater capacity to adapt to lower sowing densities, associated with higher tillering capacity than BRS Sabiá. In Ponta Grossa, BRS Sabiá gave better results than BRS Gralha-Azul for most of the variables, especially grain yield, seedling emergence, ear density, and SDM.

\section{Physiological performance of seeds}

For the variables of physiological performance of the seeds obtained in Londrina, simple effects of cultivar and vigor were observed for germination. BRS Sabiá performed better than BRS GralhaAzul, and seeds from plants that descended from vigorous seeds were better than those descended from non-vigorous seeds (Table 3). In addition, all treatments showed high germination performance ( $\geq 96 \%$ ), i.e., above $80 \%$, which is the minimum value established for wheat (MAPA, 2013), demonstrating the adaptation of these cultivars to the growing region of Londrina. 
Table 3

Summary of analysis of variance (ANOVA) and averages of the first germination count, germination, accelerated aging, seedling emergence, and emergence speed index (ESI) of two wheat cultivars, grown in Londrina, according to the initial vigor level seeds and different sowing densities

\begin{tabular}{|c|c|c|c|c|c|c|}
\hline \multirow{3}{*}{$\begin{array}{l}\text { Variation } \\
\text { Source }\end{array}$} & \multirow{3}{*}{ DF } & \multicolumn{5}{|c|}{ Medium Square } \\
\hline & & \multicolumn{5}{|c|}{ Londrina } \\
\hline & & $\begin{array}{l}\text { First germination } \\
\text { count }(\%)\end{array}$ & $\begin{array}{c}\text { Germination } \\
(\%)\end{array}$ & $\begin{array}{c}\text { Accelerated } \\
\text { aging (\%) }\end{array}$ & $\begin{array}{c}\text { Seedling } \\
\text { emergence (\%) }\end{array}$ & ESI \\
\hline Block & 3 & 0.849 & 1.75 & 21.3 & 2.83 & 0.021 \\
\hline Cultivar (C) & 1 & $43.9 * *$ & $33.1^{* *}$ & $1.89^{\text {ns }}$ & $4.00^{\text {ns }}$ & $1.34^{\mathrm{ns}}$ \\
\hline Vigor (V) & 1 & $17.0^{\text {ns }}$ & $20.3^{*}$ & $40.6^{\text {ns }}$ & $9.00^{\text {ns }}$ & $0.15^{\mathrm{ns}}$ \\
\hline Density (D) & 3 & $15.1^{*}$ & $3.63^{\text {ns }}$ & $39.1^{*}$ & $28.5^{\mathrm{ns}}$ & $1.08^{\text {ns }}$ \\
\hline $\mathrm{C} \times \mathrm{V}$ & 1 & $6.89^{\text {ns }}$ & $0.0625^{\text {ns }}$ & $47.3^{\text {ns }}$ & $0.00^{\text {ns }}$ & $0.003^{\text {ns }}$ \\
\hline$C \times D$ & 3 & $4.64^{\text {ns }}$ & $1.10^{\text {ns }}$ & $27.2^{\text {ns }}$ & $18.5^{\text {ns }}$ & $1.33^{\mathrm{ns}}$ \\
\hline$V \times D$ & 3 & $18.9^{*}$ & $4.38^{\text {ns }}$ & $24.5^{\mathrm{ns}}$ & $14.8^{\text {ns }}$ & $0.17^{\text {ns }}$ \\
\hline $\mathrm{C} \times \mathrm{V} \times \mathrm{D}$ & 3 & $30.3^{* *}$ & $5.02^{\text {ns }}$ & $15.5^{\mathrm{ns}}$ & $2.83^{\text {ns }}$ & $1.51^{*}$ \\
\hline Error & 45 & 4.99 & 3.84 & 13.4 & 14.4 & 0.53 \\
\hline CV (\%) & & 2.34 & 2.03 & 4.02 & 3.98 & 6.70 \\
\hline Factor & Treatment & $\begin{array}{l}\text { First germination } \\
\text { count }(\%)\end{array}$ & $\begin{array}{l}\text { Germination } \\
\text { (\%) }\end{array}$ & $\begin{array}{c}\text { Accelerated } \\
\text { aging (\%) }\end{array}$ & $\begin{array}{c}\text { Seedling } \\
\text { emergence (\%) }\end{array}$ & ESI \\
\hline \multirow{2}{*}{ Cultivar (C) } & Gralha-Azul & 95 & $96 b$ & 91 & 96 & 10.72 \\
\hline & Sabiá & 96 & $97 a$ & 91 & 95 & 11.01 \\
\hline \multirow{2}{*}{ Vigor (V) } & Vigorous & 96 & $97 a$ & 90 & 96 & 10.91 \\
\hline & Not-vigorous & 95 & $96 \mathrm{~b}$ & 92 & 95 & 10.81 \\
\hline \multirow{4}{*}{ Density (D) } & 150 & 96 & 97 & 91 & 95 & 11.09 \\
\hline & 250 & 96 & 97 & 91 & 94 & 10.58 \\
\hline & 350 & 95 & 96 & 93 & 97 & 11.07 \\
\hline & 450 & 95 & 96 & 90 & 95 & 10.70 \\
\hline
\end{tabular}

$\mathrm{DF}=$ degrees of freedom; $\mathrm{CV}=$ coefficient of variation. $\mathrm{ns},{ }^{*},{ }^{* *}$, and ${ }^{* *}=$ not significant, significant at $\mathrm{P} \leq 0.05, \mathrm{P} \leq 0.01$ and $\mathrm{P} \leq 0.001$, respectively, by the $\mathrm{F}$ test. Means followed by the same letters in the column, individually for the cultivar $(\mathrm{C})$ or vigor (V) factors, do not differ significantly as per the $\mathrm{F}$ test $(\mathrm{P} \leq 0.05, \mathrm{P} \leq 0.01$, or $\mathrm{P} \leq 0.001$, according to $A N O V A)$.

For accelerated aging, an isolated effect of sowing density was observed (Table 3). This characteristic was adjusted to a quadratic equation, with a peak at 291 seeds $\mathrm{m}^{-2}$ (Figure 3C).

The interaction of cultivar $x$ vigor $x$ sowing density was significant for the first germination count and ESI (Table 3). For the first germination count, BRS Gralha-Azul seeds derived from vigorous seeds showed a linear decrease in response to the increase in sowing density (Figure 3D). BRS Sabiá seeds derived from non-vigorous seeds showed a small increase in germination speed (in the first count) up to the density of 250 seeds $\mathrm{m}^{-2}$, with subsequent reduction. The seeds of 
BRS Gralha-Azul and BRS Sabiá descending from non-vigorous and vigorous seeds, respectively, did not respond to the increase in sowing density. For BRS Gralha-Azul with a density of 350 seeds $\mathrm{m}^{-2}$, seeds derived from non-vigorous seeds were superior to those descending from vigorous seeds. It was found that at a density of 450 seeds $\mathrm{m}^{-2}$, BRS Sabiá seeds derived from vigorous seeds were better than seeds derived from non-vigorous seeds of both cultivars. At the other sowing densities, there was no significant difference between the treatments.

BRS Gralha-Azul seeds derived from vigorous seeds showed a reduction of $12.6 \%$ in ESI at a density of 150 to 250 seeds $\mathrm{m}^{-2}$, with a subsequent increase at higher sowing densities (Figure 3E). However, BRS Sabiá seed descending from vigorous seeds showed the opposite trend, i.e., they presented an initial increase of $7.8 \%$ in ESI (from the density of 150 to 350 seeds $\mathrm{m}^{-2}$ ), with a subsequent decrease of $10.8 \%$ (in the density range of 350 to 450 seeds $\mathrm{m}^{-2}$ ). There was no response to the increase in sowing density for seeds descending from non-vigorous seeds for both cultivars. Finally, no differences were observed between cultivars or vigor levels for each sowing density.

The results indicate that the initial vigor of the seeds did not influence the production of quality seeds significantly. This can be attributed to the plasticity of the wheat cultivars used, combined with the edaphoclimatic conditions observed in Londrina and the appropriate cultivation techniques that contributed to compensate for the physiological limitations of non-vigorous seeds. In addition, when an appropriate stand is established, the effect of the environment is more important than the vigor of the seeds, considering the later stages of plant growth and development.

It was found that the density ranges of 250 to 350 seeds $\mathrm{m}^{-2}$ resulted in the production of seeds with better physiological quality. Higher sowing densities increased the competition between neighboring plants, causing shading and more competition for natural resources (water, nutrients, and light), resulting in less accumulation of reserves by the plants, which reduced the quality of the seeds produced.

The results reinforce the argument that the technical indication of the plant population (per unit area of a crop) must consider the purpose of the production field (seeds or grains), because the sowing density can cause morphological changes in the plants (such as number of tillers) and affect the intraspecific competition, which affects grain yield and the physiological quality of the harvested product (Nunes, Souza, \& Mercante, 2011).

Considering the objective of obtaining a higher grain yield, increasing sowing density proved to be the best strategy for the evaluated cultivars (Figures 2A and $3 \mathrm{~A}$ ). However, it is important to assess whether the production environment offers edaphoclimatic conditions favorable to the growth and development of wheat plants, so that the investment in the largest amount of seeds results in greatest economic returns. Conversely, if the purpose is to produce seeds with higher physiological quality, it is also necessary to consider the best use of environmental resources by plants, which is strongly influenced by the sowing density. In this case, high sowing densities are not suggested, because they intensify intraspecific competition. The ideal plant population to be established should provide 
adequate vegetative development and the best seed formation, which varies with the genotype and environment. In addition, the use of vigorous seeds is essential, as they have a higher germination percentage, better initial development, and allow the plasticity of the culture to be expressed (Struker et al., 2019; Abati et al., 2018), especially under unfavorable environmental conditions, providing an adequate plant stand, as reflected by higher grain yield or seed production with better physiological quality.

\section{Conclusions}

The increase in sowing density, up to the levels evaluated, favors the grain yield of wheat cultivars in both cultivation environments for vigorous and non-vigorous seeds.

The productive performance of cultivars varies depending on the production environment.

The sowing density range between 250 and 350 seeds $\mathrm{m}^{-2}$ favors the production of seeds with higher physiological performance for both wheat cultivars at the two vigor levels studied.

Vigorous seeds favor the establishment of the stand and the growth of wheat plants at the initial phenological stages; however, this does not guarantee greater grain yield.

\section{References}

Abati, J., Brzezinski, C. R., Foloni, J. S., Zucareli, C., Bassoi, M. C., \& Henning, F. A. (2017). Seedling emergence and yield performance of wheat cultivars depending on seed vigor and sowing density. Journal of Seed Science, 39(1), 58-65. doi: 10.1590/2317-1545v39n1171002

Abati, J., Brzezinski, C. R., Zucareli, C., Foloni, J. S. S., \& Henning, F. A. (2018). Growth and yield of wheat in response to seed vigor and sowing densities. Revista Caatinga, 31(4), 891-899. doi: 10.1590/ 1983-21252018v31n411rc

Bassoi, M. C., \& Foloni, J. S. S. (2015a). Cultivar de trigo BRS Sabiá: características e desempenho agronômico. Londrina: EMBRAPA Soja. Recuperado de https:// ainfo.cnptia.embrapa.br/digital/bitstream/ item/124123/1/comunicado-tecnico-84Sabia-OL.pdf

Bassoi, M. C., \& Foloni, J. S. S. (2015b). Cultivar de trigo BRS Gralha-Azul: características e desempenho agronômico. Londrina: EMBRAPA Soja. Recuperado de https:// ainfo.cnptia.embrapa.br/digital/ bitstream/ item/124119/1/comunicado-tecnico-82Gralha-OL1.pdf

Bassoi, M. C., Riede, C. R., Campos, L. A. C., Foloni, J. S. S., Nascimento, A., Jr., Arruda, K. M. A., \& Silva, S. R. (2019). Cultivares de trigo e Triticale BRS e IPR - EMBRAPA e IAPAR. Londrina: EMBRAPA Soja. Recuperado de https://www.infoteca. cnptia.embrapa.br/infoteca/bitstream/ doc/11083 76/1/Catalogotrigo20191.pdf

Carvalho, N. M., \& Nakagawa, J. (2012). Sementes: ciência, tecnologia e produção (5a ed.). Jaboticabal: FUNEP.

Empresa Brasileira de Pesquisa Agropecuária (2013). Sistema brasileiro de classificação de solos (3a ed.). Brasília: EMBRAPA Solos.

Guarienti, E. M., Ciacco, C. F., Cunha, G. R., Ducca, L. J. A., \& Camargo, C. M. O. (2005). Efeitos da precipitação pluvial, da umidade 
relativa do ar e de excesso e déficit hídrico do solo no peso do hectolitro, no peso de mil grãos e no rendimento de grãos de trigo. Ciência Tecnologia de Alimentos, 25(3), 412-418. doi: 10.1590/S0101-2061 2005000300004

Henning, F. A., Mertz, L. M., Jacob, E. A., Jr., Dorneles, R. M., Fiss, G., \& Dejalma, P. Z. (2010). Composição química e mobilização de reservas em sementes de soja de alto e baixo vigor. Bragantia, 69(3), 727-733. doi: 10.1590/S0006-87052010000300026

Long, S. P., \& Ort, D. R. (2010). More than taking the heat: crops and global change. Current Opinion in Plant Biology, 13(3), 241-248. doi: 10.1016/j.pbi.2010.04.008

Maguire, J. D. (1962). Speed of germination-aid in selection and evaluation for seedling emergence and vigor. Crop Science, 2(1), 176-177. doi: 10.2135/cropsci1962.0011 $183 \times 000200020033 x$

Ministério da Agricultura, Pecuária e Abastecimento (2009). Regras para análise de sementes. Brasília: MAPA/ACS. Recuperado de http://www.agricultura. gov.br/assuntos/laboratorios/arquivospublicacoeslaboratorio/regras-paraanalise-de-sementes.pdf/view

Ministério da Agricultura, Pecuária e Abastecimento (2013). Instrução Normativa $n^{\circ} 45$ de 2013. Secretaria de Defesa Agropecuária. Brasília: MAPA/DAS/ CSM. Recuperado de http://www.abrasem. com.br/wp-content/uploads/2012/10/ Instru\%C3\%A7\%C3\%A3o-Normativan\%C2\%BA-45-de-17-de-Setembrode - $2013-P a d r \%$ C $3 \%$ B 5 e s-de Identidade-e-Qualiidade-Prod-eComerc-de-Sementes-Grandes-Culturas-Republica\%C3\%A7\%C3\%A3oDOU-20.09.13.pdf
Ministério da Agricultura, Pecuária e Abastecimento (2015). SISZARC - Sistema de Zoneamento Agrícola de Risco Climático. Brasília: MAPA. Recuperado de http://sistemasweb.agricultura.gov.br/ siszarc/gerarRelatorioRelacaoCultivares. action?sgJAASAplicacaoPrincipal=siszarc

Ministério da Agricultura, Pecuária e Abastecimento (2020). A Pandemia da COVID-19 e as perspectivas para o setor agrícola brasileiro no comércio internacional. Secretaria de Comércio e Relações Internacionais. Brasília: MAPA.

Mondo, V. H. V., Cicero, S. M., Dourado, D., Neto, Pupim, T. L., \& Dias, M. A. N. (2012). Vigor de sementes e desempenho de plantas de milho. Revista Brasileira de Sementes, 34(1), 143-155. doi: 10.1590/S0101-3122 2012000100018

Nunes, A. S., Souza, L. C. F., \& Mercante, F. M. (2011). Adubos verdes e adubação mineral nitrogenada em cobertura na cultura do trigo em plantio direto. Bragantia, 70(2), 432-438. doi: 10.1590/S0006-87052011 000200026

Ohlson, O. de C., Krzyzanowski, F. C., Caieiro, J. T., \& Panobianco, M. (2010). Teste de envelhecimento acelerado em sementes de trigo. Revista Brasileira de Sementes, 32(4), 118-124. doi: 10.1590/S0101-3122 2010000400013

Oliveira, S., Tavares, L. C., Lemes, E. S., Brunes, A. P., Dias, I. L., \& Meneghello, G. E. (2014). Tratamento de sementes de Avena sativa L. com zinco: qualidade fisiológica e desempenho inicial de plantas. Semina: Ciências Agrárias, 35(3), 1131-1142. doi: 10.5433/1679-0359.2014v35n3p1131 
Ramme, F. L. P., Lamparelli, R. A. C., \& Rocha, J. V. (2010). Perfis temporais NDVI MODIS, na cana-soca, de maturação tardia. Engenharia Agrícola, 30(3), 4802-494. doi: 10.1590/S0100-69162010000300012

Rossi, R. F., Cavariani, C., \& França, J. de B., Neto. (2017). Vigor de sementes, população de plantas e desempenho agronômico de soja. Revista de Ciências Agrárias, 60(3), 215-222. doi: 10.4322/rca.2239

Sbrussi, C. A. G., \& Zucareli, C. (2014). Germinação de sementes de milho com diferentes níveis de vigor em resposta à diferentes temperaturas. Semina: Ciências Agrárias, 35(1), 215-226. doi: 10. 5433/1679-0359.2014v35n1p215

Silva, R. R., Benin, G., Silva, G. O., Marchioro, V. S., Almeida, J. L., \& Matei, G. (2011). Adaptabilidade e estabilidade de cultivares de trigo em diferentes épocas de semeadura, no Paraná. Pesquisa Agropecuária Brasileira, 46(11), 14391447. doi: 10.1590/S0100-204X201100 1100004

Silva, S. R., Bassoi, M. C., \& Foloni, J. S. S. (2018). Informações técnicas para trigo e triticale - safra 2019. Anais da Reunião da Comissão Brasileira de Pesquisa de Trigo e Triticale, Brasília, DF, Brasil. Recuperado de https://www.embrapa.br/en/buscade-publicacoes/-/publicacao/1108443/ informacoes-tecnicas-para-trigo-etriticale---safra-2019
Struker, S., Carvalho, I. R., Szareski, V. J., Barbosa, M. H., Souza, V. Q., Conte, G. G.,... Aumonde, T. Z. (2019). Influence of seeds vigor in the attributes of soybean yield. Revista de Ciências Agrárias, 42(3), 698703. doi: 10.19084/rca.16389

Tavares, L. C. V., Foloni, J. S. S., Bassoi, M. C., \& Prete, C. E. C. (2014). Genótipos de trigo em diferentes densidades de semeadura. Pesquisa Agropecuária Tropical, 44(2), 166-174. doi: 10.1590/S1983-40632014 000200010

Valério, I. P., Carvalho, F. I. F. de, Benin, G., Silveira, G. D., Silva, J. A. G. D., Nornberg, R.,... Oliveira, A. C. D. (2013). Seeding density in wheat: the more, the merrier? Scientia Agricola, 70(3), 176-184. doi: 10.1590/S0103-90162013000300006

Valério, I. P., Carvalho, F. I. F. de, Oliveira, A. C., Benin, G., Maia, L. C., Silva, J. A. G.,... Silveira, G. (2009). Fatores relacionados à produção e desenvolvimento de afilhos em trigo. Semina: Ciências Agrárias, 30(1), 1207-1218 doi: 10.5433/1679-0359.20 09v30n4Sup1p1207

Valério, I. P., Carvalho, F. I. F. de, Oliveira, A. C., Machado, A. A., Benin, G., Scheeren, P. L.,... Hartwig, I. (2008). Desenvolvimento de afilhos e componentes do rendimento em genótipos de trigo sob diferentes densidades de semeadura. Pesquisa Agropecuária Brasileira, 43(3), 319-326. doi:10.1590/S0100-204X2008000300005 